Magdalena Zych

Muzeum Etnograficzne im. Seweryna Udzieli w Krakowie

we współpracy z

Jackiem Kukuczką (Muzeum Etnograficzne im. Seweryna Udzieli w Krakowie), Grażyną Kubicą-Heller (Instytut Socjologii Uniwersytetu Jagiellońskiego), Andrzejem Dybczakiem (Kraków)

\title{
Cztery spojrzenia na badawczy projekt muzealny na temat kolekcji syberyjskiej Muzeum Etnograficznego w Krakowie
}

Tematy, które nas szczególnie interesują, na ogół wyrastają z pierwszych fascynacji. Jednak droga od delikatnego i nieubranego w żaden konkret zainteresowania do tworzenia wiedzy opartej na właściwym warsztacie zwykle jest dość długa. Tak samo było w moim przypadku. Niedawno znalazłam zeszyt z notatkami z czasów, kiedy czytałam jako nastolatka książkę Podróże do piekieł. Rzecz o szamańskich misteriach Jerzego Wasilewskiego. Być może była to jedna z lektur polecanych do przeczytania przed egzaminem na etnologię, nie pamiętam okoliczności, w jakich sięgnęłam po tę książkę. Przerysowałam tuszem ze zdjęć zamieszczonych w książce elementy stroju szamańskiego i wkleiłam je do zeszytu między notatki i cytaty. Potem były inne książki, studia, czasem temat syberyjski powracał, jak wtedy gdy z krakowskim teatrem offowym Eloe działającym przy ówczesnej PWST przygotowaliśmy adaptację Anhellego, w której odpowiadałam za oprawę muzyczną. Później byłam zaangażowana w produkcję filmu dokumentalnego Gugara, który rozgrywał się pośród ewenkijskich pasterzy reniferów, a jego reżyserami byli Andrzej Dybczak i Jacek Nagłowski. Po latach, gdy okazało się, że w miejscu, które stało się miejscem mojej pracy, jest niezwykły zbiór przedmiotów z Syberii, pozostawało tylko 
w jakiś sposób sprawić, by mogły przemówić, by stały się czymś w rodzaju biletu dla osób z nimi związanych, kiedyś i teraz.

Pomysł, by stworzyć odpowiednie warunki do interpretacji przedmiotów pochodzących z terenów Syberii zaczęłam realizować w Muzeum Etnograficznym w 2014 roku. Próbowałam pozyskać środki na badanie kolekcji w jednym z konkursów dla doktorantów, ale plany te się nie powiodły, należało dopracować pomysł. Wiązało się to także ze zwiększeniem jego skali — jasne stało się, że warto objąć badaniami cały zbiór i rozpisać pracę na kilka lat. Pierwszym krokiem było powołanie zespołu oraz ram dających szansę na pomyślną realizację badań. Od początku stało za nimi założenie równoległego odczytywania archiwów i współczesnych kontekstów w miejscach pochodzenia kolekcji. Pracowałam w MEK od 2008 roku koordynując projekty badawcze skupione na dwóch wątkach polskiej kultury współczesnej - temacie ogrodów działkowych i zmieniającej się obrzędowości weselnej. W obydwu przypadkach była to także praca z kolekcją oraz różne eksperymenty w czasie prowadzonych przez zespoły badań terenowych. Jednak w pomyśle szerokiego badania zbiorów syberyjskich istotne było to, że tym razem to kolekcja miała stać się punktem wyjścia do zaprojektowania badań oraz do znalezienia osób, których współpraca przyniesie dobre rezultaty.

Po różnych przymiarkach powstał zespół. Grażyna Kubica-Heller specjalizująca się m.in. w pracy ze źródłami etnograficznymi - w tym kontekstem syberyjskim oraz metodologicznym, zgodziła się kierować zespołem. Znaleźli się w nim, oprócz mnie, kustosz Jacek Kukuczka, doświadczony kurator i bezpośredni opiekun m.in. kolekcji syberyjskiej, oraz Andrzej Dybczak, artysta (pisarz, filmowiec), ale także etnolog, który miał już doświadczenie w pracy dokumentacyjnej na Syberii oraz biegle posługiwał się audiowizualnymi środkami rejestracji. Już w 2014 roku był zainteresowany kolekcją syberyjską MEK, w 2008 roku na zaproszenie Katarzyny Barańskiej pokazywał w muzeum film Gugara, nagrodzony wówczas Złotym Lajkonikiem na Krakowskim Festiwalu Filmowym. W czasie tworzenia zespołu i szukania źródeł finansowania okazało się, że najlepiej będzie, jeśli w tym niewielkim, czteroosobowym gronie, podejmiemy się realizacji zadania, które otrzymało w 2016 roku w konkursie Narodowego Programu Rozwoju Humanistyki grant. Kształt przedsięwzięcia był wypadkową wspólnej pracy, gdyż przez kilka miesięcy w 2015 roku przygotowywaliśmy się do konkursu. Także dla instytucji była to nowa sytuacja, bowiem do tego czasu MEK nie finansował 
badań środkami pochodzącymi z konkursów dla instytucji naukowych. Dzięki poparciu dla pomysłu dyrekcji Muzeum i wspólnej pracy nad wnioskiem konkursowym uzyskaliśmy finansowanie tych badań.

W naszym zespole spotkały się zróżnicowane perspektywy i pozwoliły wypracować założenia badawcze, drogi ich realizacji a potem przeprowadzić skutecznie badania, by następnie opowiadać o rezultatach, poprzez liczne materiały opublikowane w Internecie na stronie muzeum. Jest tam dostępna cała kolekcja w postaci bazy danych oraz konteksty z badań terenowych np. w części Historie oraz Gtosy z terenu.

Dzięki osobno pozyskanym środkom w konkursie Ministerstwa Kultury i Dziedzictwa Narodowego mogliśmy przygotować wystawę „Syberia. Głosy z Północy” (16.10.2020-31.12.2021) wzbogaconą programem spotkań i dodatkowych wydarzeń „Syberia. Dopowiedzenia” — program ten wsparł sponsor, firma Gaz-System S.A. Sama wystawa, przygotowywana jeszcze przed pandemią, musiała przejść na etapie scenariusza metamorfozę, konieczne było dostosowanie jej kształtu do pandemicznych ograniczeń. Z tego powodu, ważne miejsce naszych działań, czyli magazyn studyjny, nie był dostępny dla publiczności.

Zachęceni przez Redakcję ZWAM postanowiliśmy podzielić się refleksjami na temat prowadzenia badań tego rodzaju w ramach działalności naukowej muzeum etnograficznego. Czy nasze działania są odpowiedzią na wezwanie Iwana Gaskella opublikowane na łamach ZWAM przed dwoma laty (pierwodruk w 2017), by muzeum stało się miejscem wielkich idei? Tworząc wspólnie z naszymi rozmówcami w różnych miejscach Północy wiedzę na temat kolekcji, staraliśmy się w odpowiedzialny sposób traktować kolekcję jako szansę na spotkanie i opowieść, stworzyć warunki, by ujawniła się jej wartość, siła oddziaływania. Mamy nadzieję, że chociaż częściowo udało się pójść drogą rozumienia kolekcji i rozwijania jej znaczeń w stronę przyszłości.

\footnotetext{
${ }^{1}$ Zespół kuratorski wystawy: Andrzej Dybczak, Jacek Kukuczka, Anna Zabdyrska, Magdalena Zych.

${ }^{2}$ Program obejmuje specjalne relacje z magazynu studyjnego i wystawy („Benedykt Dybowski przesiedla renifery”, „Konstanty Podhorski w gorączce złota”, „Tajemnice magazynu kolekcji syberyjskiej”) oraz dyskusje na wybrane tematy z zaproszonymi gośćmi („Udział Polaków w kolonizacji Syberii”, „Syberia w reportażu”, „Ludzie i zwierzęta”, „Północ zmienia swój klimat”, „Kolekcje etnograficzne w XXI wieku”, „Delikatna materia — o konserwacji kolekcji syberyjskiej”). Nagrania spotkań są dostępne na kanale YouTube MEK. Zrealizowano także spacer śladami kolekcji po Krakowie „Syberyjski Kraków”, jego trasa w postaci podcastów zostanie udostępniona. Specjalny program edukacji o zmianach klimatu włączający wyniki tych badań będzie realizowany od września 2021 r. w ramach oferty stałej dla szkół.
} 
W tym tekście znajdą się fragmenty napisane przez Jacka Kukuczkę, Grażynę Kubicę-Heller i Andrzeja Dybczaka, a także opowieść o samych badaniach oparta na raportach i relacjach, które powstawały między 2016 a 2019 rokiem.

1.

Głos Jacka Kukuczki, kustosza kolekcji, na temat jej kontekstu muzealnego i decyzji o nie powiększaniu w trakcie badań tego zbioru:

„Kolekcja syberyjska Muzeum Etnograficznego im. Seweryna Udzieli w Krakowie - a raczej historyczne zbiory syberyjskie muzeum — sięgają korzeniami głęboko w XIX wiek. Jest to najstarszy i najprawdopodobniej najliczniejszy zespół unikatowych obiektów obrazujących kultury rdzennych mieszkańców dalekiej północy i wschodnich krańców Rosji, jaki znajduje się polskich zbiorach muzealnych. W polskiej historiografii i zarazem etnografii, obszary te - niezbyt precyzyjnie — przyjęło się określać uniwersalnym terminem: Syberia.

„Kapitał” muzealnej kolekcji syberyjskiej narastał przez wiele dekad a sama kolekcja stała się jedną z wizytówek zbiorów pozaeuropejskich, które niemal od momentu powstania muzeum w 1911 roku były jego integralną częścią. Obiekty syberyjskie trafiały do muzeum różnymi drogami, a scalanie samej kolekcji trwało od 1913 roku do ostatniej dekady XX wieku. W tym czasie, pomimo niepełnych danych, szczątkowych informacji i nieprecyzyjnych opracowań, funkcjonowały one na wielu wystawach w Krakowie i poza siedzibą samego muzeum. Od swych początków sięgających w wielu przypadkach czasów przed powstaniem muzeum, kolekcja syberyjska żyła na miarę ówczesnych możliwości i ograniczeń wynikających w dużej mierze z zawiłej i trudnej historii XX wieku. Upływający czas oddalał ją jednak od źródeł — zacierały się archiwalne metki, dokumentacja krążąca pomiędzy instytucjami „gubiła” historyczne dane a polityczne zmiany nie sprzyjały pogłębianiu wiedzy na temat „trudnych tematów”, które zawarte były w biografiach darczyńców. Paradoks polegał na tym, że wartość syberyjskiego zbioru rosła lecz nie szła w parze z wiedzą i rozumieniem samej kolekcji — ludzi, którzy ją stworzyli oraz mieszkańców Syberii, którym ją zawdzięczamy.

XXI wiek przyniósł nowe możliwości i wyzwania. Archiwalne dane i stare opracowania nie wytrzymywały już próby czasu - powstawały wciąż nowe pytania lecz brak było wystarczająco pełnych i wiarygodnych 
odpowiedzi. Świadomość takiego stanu rzeczy zrodziła pilną potrzebę opisania tej kolekcji nie tyle od nowa, co z uwzględnieniem współczesnej perspektywy, w której głos „stamtąd” — z Syberii byłby równie ważny a może nawet ważniejszy, niż etnograficzne interpretacje kuratorów. Aby tego dokonać, muzeum musiało przebić się przez „szklany sufit” - przekroczyć własne progi i wyruszyć na... Syberię. Okazało się to możliwe za sprawą projektu naukowo-badawczego Antropologiczna reinterpretacja kolekcji syberyjskiej ze zbiorów Muzeum Etnograficznego w Krakowie, pochodzacej od polskich badaczy Syberii XIX wieku, realizowanego w ramach grantu NPRH w latach 2016-2019. Ten interdyscyplinarny program badawczy objął swoim zasięgiem nie tylko klasyczne badania terenowe (realizowane w 4 wyselekcjonowanych i powiązanych z kolekcją lokalizacjach), ale również badania nad analogicznymi kolekcjami w Rosji i Wielkiej Brytanii. Celem zarówno jednych jak i drugich było przeniesienie uwagi z przeszłości na współczesność rozumienia samej kolekcji jak i historii, które w sobie przez ponad sto lat skrywała. Kto i dlaczego pozyskał te obiekty? Czemu, komu i w jakich celach używano tych rzeczy zanim stały się muzealnym obiektem? Czy są nadal „żywe” i funkcjonują wśród potomków ich dawnych właścicieli? Czego możemy się od nich dowiedzieć o rzeczach stanowiących obecnie część naszego dziedzictwa? To tylko kilka wybranych pytań, z którymi muzeum ruszyło w teren do archiwów, magazynów i na Syberię — od Półwyspu Kanin do Czukotkę i Kamczatkę. Niemal każdy z 350 obiektów tworzących historyczny zbiór wymagał „dopytania” i doprecyzowania. I choć pytania wydawały się proste, znalezienie odpowiedzi wcale nie było łatwe. Syberyjska kolekcja Muzeum Etnograficznego w Krakowie choć pozornie nieliczna - w skali pokrewnych kolekcji znajdujących się w muzeach rosyjskich i zachodnioeuropejskich — okazała się być niezwykle bogata. Za często unikatowymi obiektami kryły się osobiste historie dotykające sfer tak intymnych jak małżeństwo (nieniecki kapor - obrzędowe nakrycie głowy 19106/MEK), wierzenia religijne (selkupskie figurki kultowe 30609/MEK i 30610/MEK) czy wreszcie trudnych jak okoliczności i sposoby pozyskania obiektów lub całych kolekcji (np. kolekcja Konstantego Podhorskiego).

Najważniejszą, wzbudzającą żywe zainteresowanie, ale i kontrowersję w środowisku etnografów i muzealników była jednak decyzja o niegromadzeniu w trakcie badań nowych obiektów i nierozbudowywaniu zbioru o rzeczy, lecz o wiedzę umożliwiającą rozumienie historycznej 
kolekcji. Nie był to ortodoksyjny paradygmat ani bezwzględna zasada w trakcie spotkania, rozmowy czy wywiadu uczestnicy badań spotykali się ze spontanicznymi, żywymi reakcjami, wśród których kategoria daru wymagała uszanowania woli naszych rozmówców. Te sytuacje były gestem w stronę muzeum i samych badaczy, a pozyskane w ten sposób obiekty są nieliczne, co nie znaczy, że mniej ważne. Warto z całą mocą podkreślić, że zadaniem uczestników projektu badawczego było przywrócenie tej kolekcji do życia, poprzez przybliżenie stojących za nią ludzi — zarówno postaci historycznych jak i współczesnych mieszkańców wybranych regionów Syberii. Wiedzieliśmy, że niemal każda rzecz z kolekcji syberyjskiej skrywa w sobie jakąś opowieść. Niektórych z nich udało nam się wysłuchać i dziś wybrzmiewają na stronie - portalu www.etnomuzeum.eu/syberia oraz na wystawie „Syberia. Głosy z Północy”.”

2.

Refleksje osobiste Grażyny Kubicy-Heller, doktor habilitowanej, antropolożki, kierującej w swej pracy uwagę w stronę archiwów etnograficznych i metodologii:

„Syberia znajdowała się w sferze moich historycznych zainteresowań od kiedy zajmowałam się badaniem biografii i twórczości Marii Czaplickiej, oksfordzkiej antropolożki, która poprowadziła ekspedycję jenisejską w latach 1914-1915, a jeszcze wcześniej napisała książkę Aboriginal Siberia. A Study in Social Anthropology, będącą omówieniem całej ówczesnej etnografii plemion syberyjskich aborygenów (pisanej głównie po rosyjsku i polsku). To właśnie przez teksty i zdjęcia tej badaczki patrzyłam na „Kanadę wschodu”, jak zwykła była nazywać Syberię. Jednocześnie kraina ta wywoływała konotacje związane z dramatami polskich zesłańców popowstaniowych, a także z Archipelagiem Gułag Aleksandra Sołżenicyna, czytanym w samizdacie, czy Innym światem Herlinga Grudzińskiego.

Praca na kolekcją syberyjską krakowskiego Muzeum Etnograficznego połączyła te dwa tropy: etnograficzny i martyrologiczny, bowiem większość jej obiektów pochodzi od polskich zesłańców zainteresowanych kulturami rdzennych ludów Syberii. Przywieźli ze sobą bogato zdobioną odzież ze zwierzęcych skór, przedmioty codziennego użytku, ale też modele czółen czy narzędzi.

Mimo iż byłam już obyta z syberyjskimi artefaktami z kolekcji Czaplickiej w Pitt Rivers Museum w Oksfordzie, to praca nad krakowskim zbio- 
rem stanowiła dla mnie zupełnie nową jakość. Przede wszystkim został on ulokowany w jednym miejscu: sali magazynowej zwanej „stolarnią”. Tam mieściło się centrum naszej aktywności. Obiekty znajdowały się w szufladach wielkiej komody, a także w pudłach na licznych półkach. Mogliśmy je w każdej chwili wyjąć obejrzeć i (ostrożnie) dotykać. To intymne obcowanie z tymi delikatnymi ubraniami, które jednak zachowały swoją formę i piękno zdobień, było doniosłym przeżyciem. Oglądaliśmy wnikliwie każdą sztukę, staraliśmy się dociec z czego była zrobiona i w jaki sposób. Odnajdywaliśmy wszystkie informacje z poprzednich katalogowań, porównywaliśmy je ze sobą i naszą wiedzą o kontekście, próbowaliśmy odnaleźć w Internecie podobne rzeczy, pytaliśmy ekspertów. Staraliśmy się także łączyć poszczególne rzeczy ze sobą: spodnie, kurtki, nakrycia głowy, rękawiczki. Odtwarzaliśmy w ten sposób pierwotne całości strojów, które zostały rozdzielone w poprzednich porządkowaniach muzealnych. Rozkładaliśmy poszczególne elementy strojów z jednego regionu na pokrytej płachtami papieru podłodze. Staraliśmy się wyobrazić kim byli ludzie, którzy je nosili, jak wyglądali, co robili. Wymyślaliśmy biografie tych ubrań i historie ludzi. Ta praca uruchamiała naszą wyobraźnię i skłaniała do dalszych poszukiwań.

Bardzo ważne było w tej działalności to, że pracowaliśmy jako zespół: każde z nas dorzucało jakiś element do wspólnego przedsięwzięcia. Jacek Kukuczka dzielił się swoją bogatą wiedzą wieloletniego kustosza zbiorów pozaeuropejskich MEK, Andrzej Dybczak odwoływał się do swojego doświadczenia z pobytów na Syberii, Magdalena Zych uruchamiała swoją rozległą wiedzę teoretyczną dotyczącą muzeologii i współczesnej etnologii. Ja porównywałam zbiory syberyjskie MEK do kolekcji Czaplickiej i dzieliłam się swoją wiedzą antropologiczną i historyczną dotyczącą badań Syberii oraz herstoryczną, która okazała się bardzo przydatna bo część darczyńczyń uczestniczyło w kursach dla kobiet organizowanych przez Adriana Baranieckiego, jednocześnie twórcy Muzeum Techniczno-Przemysłowego, pierwotnego locum obiektów kolekcji syberyjskiej MEK. Bardzo mnie ucieszyło, że to właśnie emancypujące się kobiety, które starały się zdobywać wyższe wykształcenie, przysłużyły się powstaniu bogatej kolekcji syberyjskiej.

W tym projekcie najbardziej mnie urzekła możliwość nieśpiesznego i bliskiego obcowania z rzeczami, nadawania im znaczenia, wgłębiania się w ich historię, nadawania im sprawczości. A z drugiej strony: praca zespo- 
łowa w najlepszym tego słowa znaczeniu, demokratyczna i współdziałająca, oparta na wzajemnej sympatii i szacunku, kolektywnym podejmowaniu wszystkich decyzji, negocjowaniu każdego kolejnego etapu projektu.

Warte wspomnienia są także inne przedsięwzięcia: rozmowy z byłą dyrektorką MEK, Marią Zachorowską, która przez długi czas opiekowała się zbiorami pozaeuropejskimi, Alicją Małetą, Andrzejem Ratajem oraz innymi osobami związanymi z tym zbiorem w samym muzeum (rozmowa z kustosz Magdaleną Dolińską czy z dr. Jerzym Czajkowskim w Sanoku, autorem wczesnego opracowania kolekcji w l. 50. XX w.) a także naszymi gośćmi: z Rosji dr. Jurijem Kwaszninem z Rosyjskiej Akademii Nauki w Tjumeniu, oraz z Niemiec dr. Erichem Kastenem, szefującym Fundacji Kultur Syberyjskich, a wcześniej prowadzącym program badań syberyjskich w Instytucie Maxa Plancka. Kolekcję konsultowaliśmy także z dr. Peterem Kulchyskim, specjalistą native studies, kanadyjskim badaczem z University of Manitoba, a także z prof. Timem Ingoldem z University of Aberdeen, który gościł w magazynie studyjnym w 2019 roku. Bardzo ważne były nasze studyjne wyjazdy do Petersburga, gdzie odwiedziliśmy tamtejsze muzea etnograficzne z bogatymi zbiorami syberyjskimi i kompetentnymi kustoszami, którzy bardzo nam pomogli w kontekstualizowaniu naszego zbioru, jednocześnie krytycznie odnosząc się do dawniejszych praktyk pozyskiwania zbiorów przez etnograficzne ekspedycje za czasów komunistycznych, pustoszące ze wszystkiego „inorodcze wioski”. Wyjazd do Oksfordu i tamtejszego Pitt Rivers Museum też był bardzo owocny, choć tym razem to raczej my pomagaliśmy naszym brytyjskim koleżankom. Był to wyjazd zogniskowany na próbie odpowiedzi na pytanie, czy kultowe figurki, będące w krakowskiej kolekcji nie były przypadkiem podarowane przez Marię Czaplicką, bo podobna figurka znajdowała się także w oksfordzkim muzeum. Jednak wyprawa w teren Andrzeja Dybczaka nie potwierdziła tej hipotezy. Nie znaleźliśmy także żadnych dokumentów potwierdzających związki Czaplickiej z krakowskimi instytucjami naukowymi po jej powrocie z Syberii.

Innym interesującym wątkiem naszego projektu były poszukiwania dotyczące darczyńców kolekcji syberyjskiej. Niektóre osoby, jak Benedykt Dybowski, zesłaniec-naukowiec, były nam dobrze znane, choć i w jego przypadku udało nam się odnaleźć ciekawe źródła. Inną ważną postacią był Konstanty Podhorski, ziemianin z Kresów, który sprzedał swój majątek i wyruszył na Alaskę w poszukiwaniu złota, współtworzył kompanię han- 
dlową, która miała eksploatować Czukotkę. Napisał trawelog, gdzie znalazło się wiele ciekawych etnograficznie fragmentów dotyczących przedstawicieli rdzennych ludów, a także zgromadził sporą kolekcję przedmiotów sztuki użytkowej Czukczów. Został zamordowany przez męża uwiedzionej przez siebie kobiety. Było oczywiście także sporo darczyńców-zesłańców, którzy po powrocie z katorgi przekazywali do krakowskich muzeów swoje syberyjskie ubrania i pamiątki. Darczyńcami byli także specjaliści, którzy na Syberii pracowali: w leśnictwie, czy administracji”.

\section{3.}

Powyższe głosy Jacka Kukuczki i Grażyny Kubicy-Heller wystarczająco naświetlają kontekst pracy naszego zespołu. Warto teraz przywołać wszystkie miejsca, gdzie temat kolekcji syberyjskiej MEK zawitał w czasie badań. Fotografie lub nagrania wideo kolekcji były systematycznie zabierane w podróż, służyły za kanwę rozmów. Wyjazdy wymagały starannej oprawy administracyjnej - do pracy w rosyjskiej strefie przygranicznej oprócz wiz wymagane są specjalne pozwolenia wydawane przez Federalną Służbę Bezpieczeństwa, która czuwa nad przebiegiem takich badań prowadzonych przez obcokrajowców. By zezwolenie uzyskać należy dostarczyć imienne poręczenie lokalnej instytucji, ale należy je uzyskać przed wjazdem na terytorium Federacji Rosyjskiej. Wiele razy nieznający nas pracownicy i szefowie lokalnych muzeów ręczyli swoim stanowiskiem, co właściwie było jedynym sposobem, by badania mogły się odbyć. W kilku przypadkach spotykali się z odmową, musieli ponawiać swe starania. To zachowanie udowadnia, że muzealny świat pełen jest połączeń przekraczających sprawy, które mogłyby ograniczyć współpracę.

Warte uwagi jest także i to, że audiowizualna rejestracja sprzętem, którego transport i strona techniczna są możliwe do obsłużenia przez jedną osobę, to szansa technologiczna, którą ten projekt wykorzystał. Oczywiście notatki i rysunek to najporęczniejszy sposób zapisu w czasie badań, ale w wielu sytuacjach dyskretny sposób dokumentacji, która nikomu nie przeszkadza, nie narzuca się, a może posłużyć wartościowemu wsparciu opowieści o kolekcji, to ważny wymiar tej pracy. W bagażu znalazły się więc: dwa aparaty fotograficzne z funkcją rejestracji filmowej, różne obiektywy, laptop, rejestrator, statyw, dyski przenośne, mikrofon, mikroporty, zestawy kabli, baterii i akumulatorów. 
Wspólnie zdecydowaliśmy o najważniejszych kierunkach geograficznych w ślad za wybranymi elementami kolekcji.

Dwie figurki kultowe sprawiły, że dwukrotnie Andrzej Dybczak prowadził badania w społeczności Selkupów w Jamalsko-Nienieckim Okręgu Autonomicznym na Syberii Zachodniej. To okolice rzeki Taz, miejscowości Ratta i Krasnoselkup oraz osady leśne dopływów tej rzeki. Pierwszy wyjazd projektu miał miejsce w październiku 2016 roku, trwał miesiąc, drugi po-

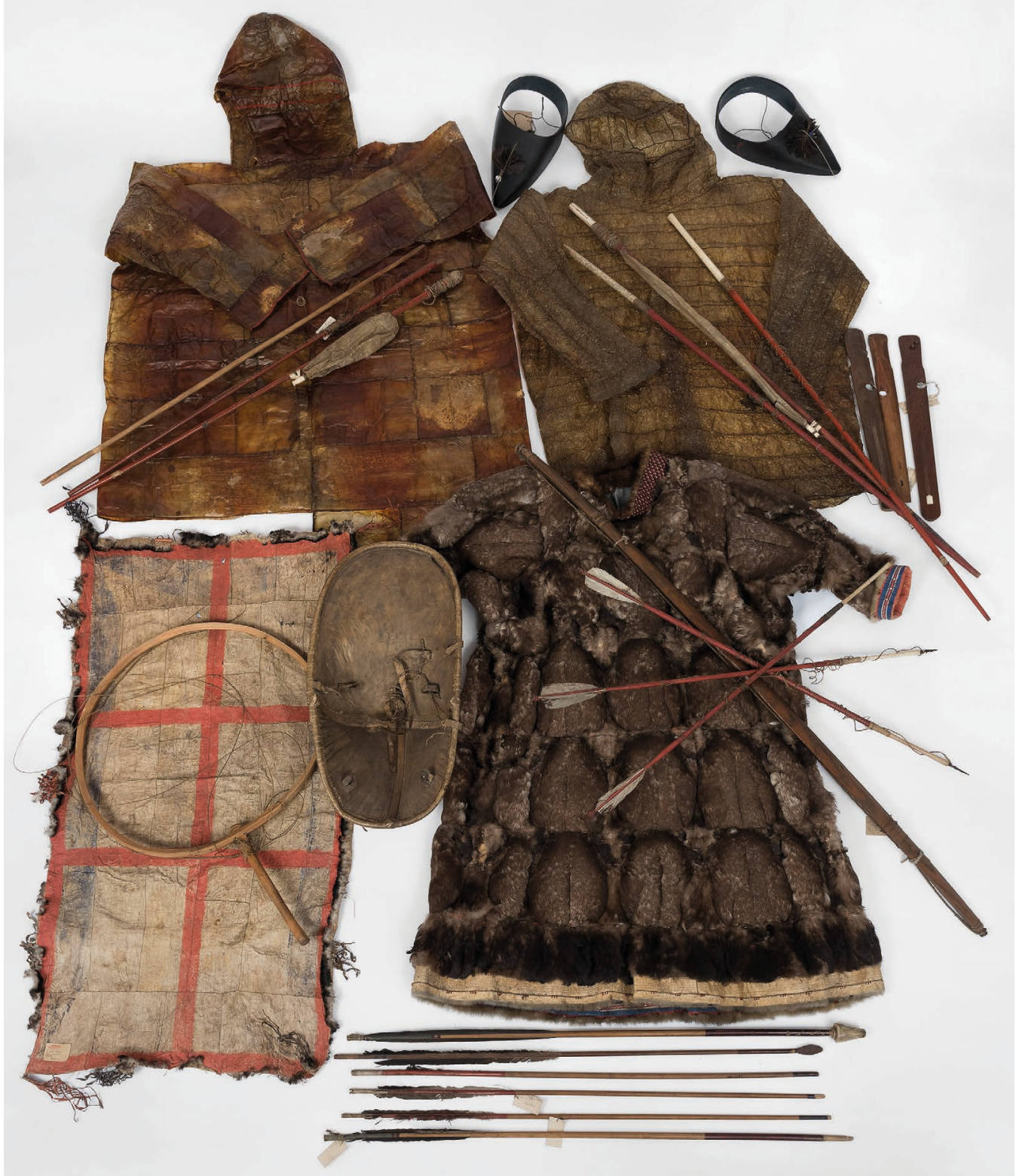

Il. 1. Przedmioty aleuckie ze zbiorów Benedykta Dybowskiego, fot. W. Wilczyk, Muzeum Etnograficzne w Krakowie 


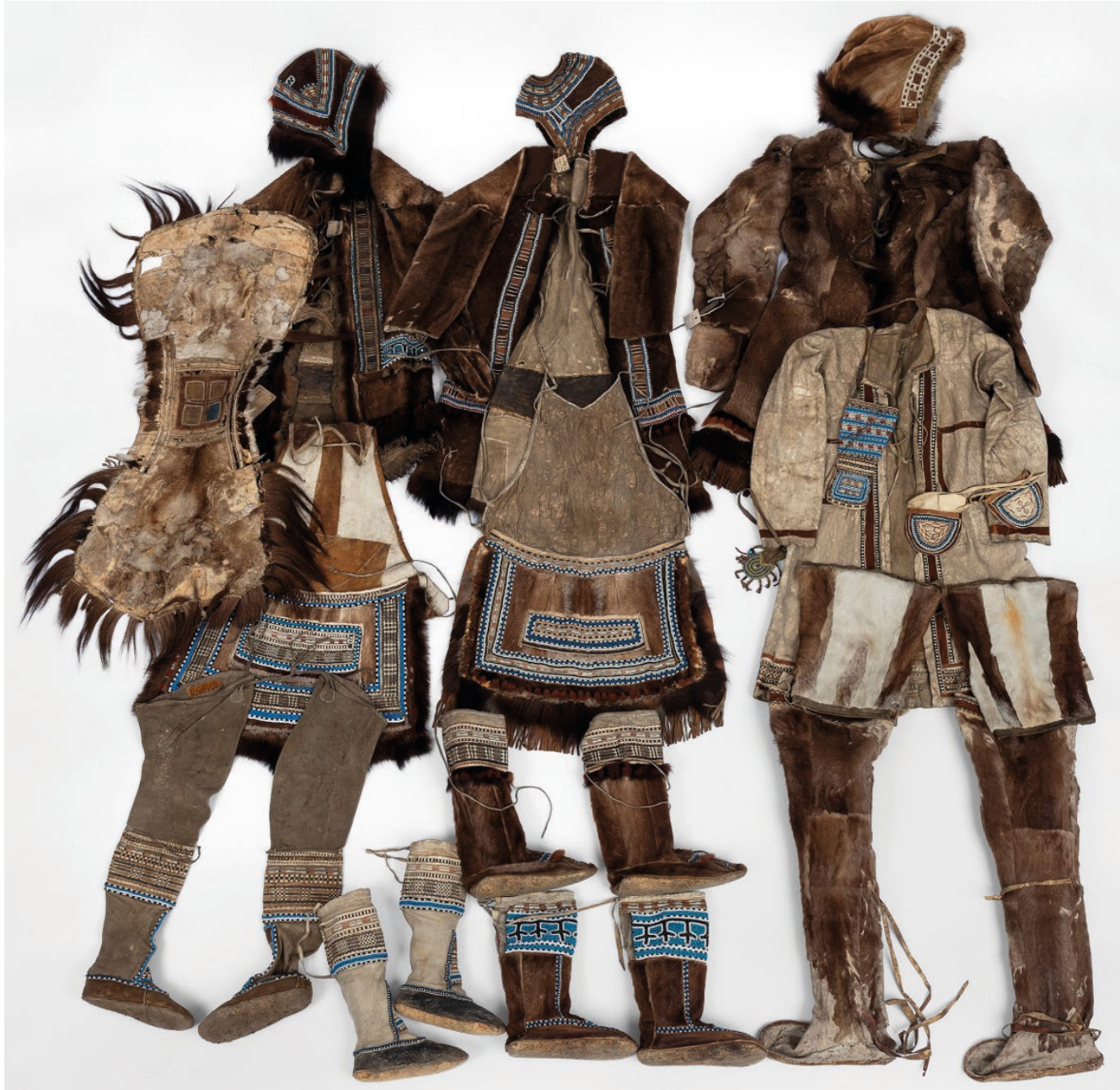

Il. 2. Przedmioty aleuckie ze zbiorów Benedykta Dybowskiego, fot. W. Wilczyk, Muzeum Etnograficzne w Krakowie

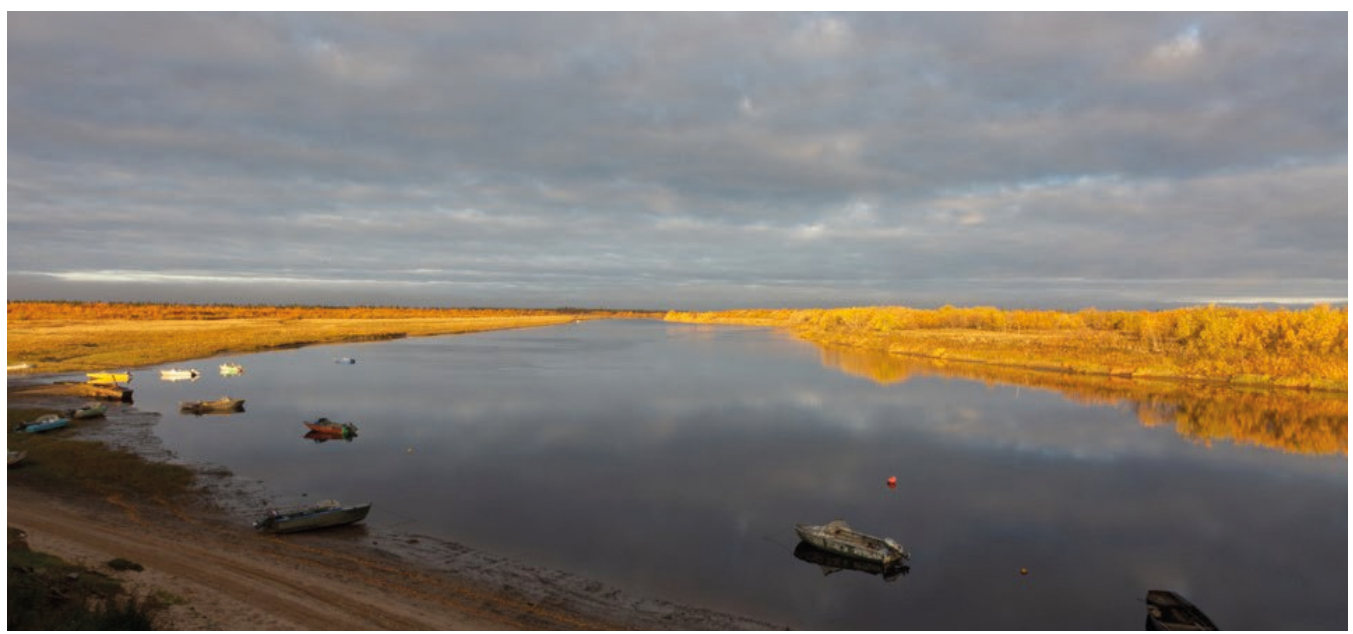

Il. 3. Rzeka Oma, okolice Morza Barrentsa, Nieniecki Okręg Autonomiczny, fot. A. Dybczak, Muzeum Etnograficzne w Krakowie 


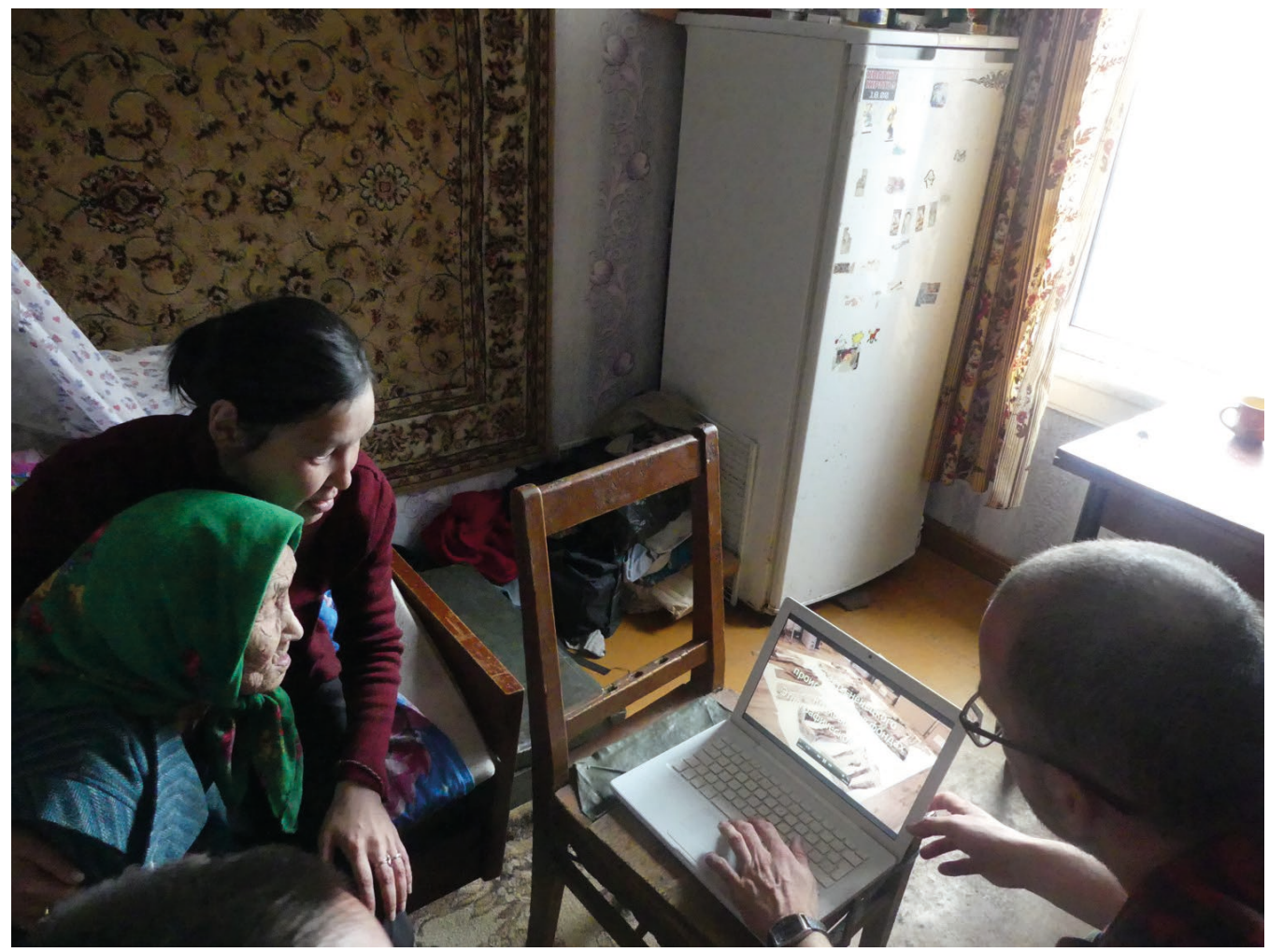

Il. 4. Konsultacje w Nelmnyj Nos, Nieniecki Okręg Autonomiczny, 2017, fot. J. Kukuczka, Muzeum Etnograficzne w Krakowie

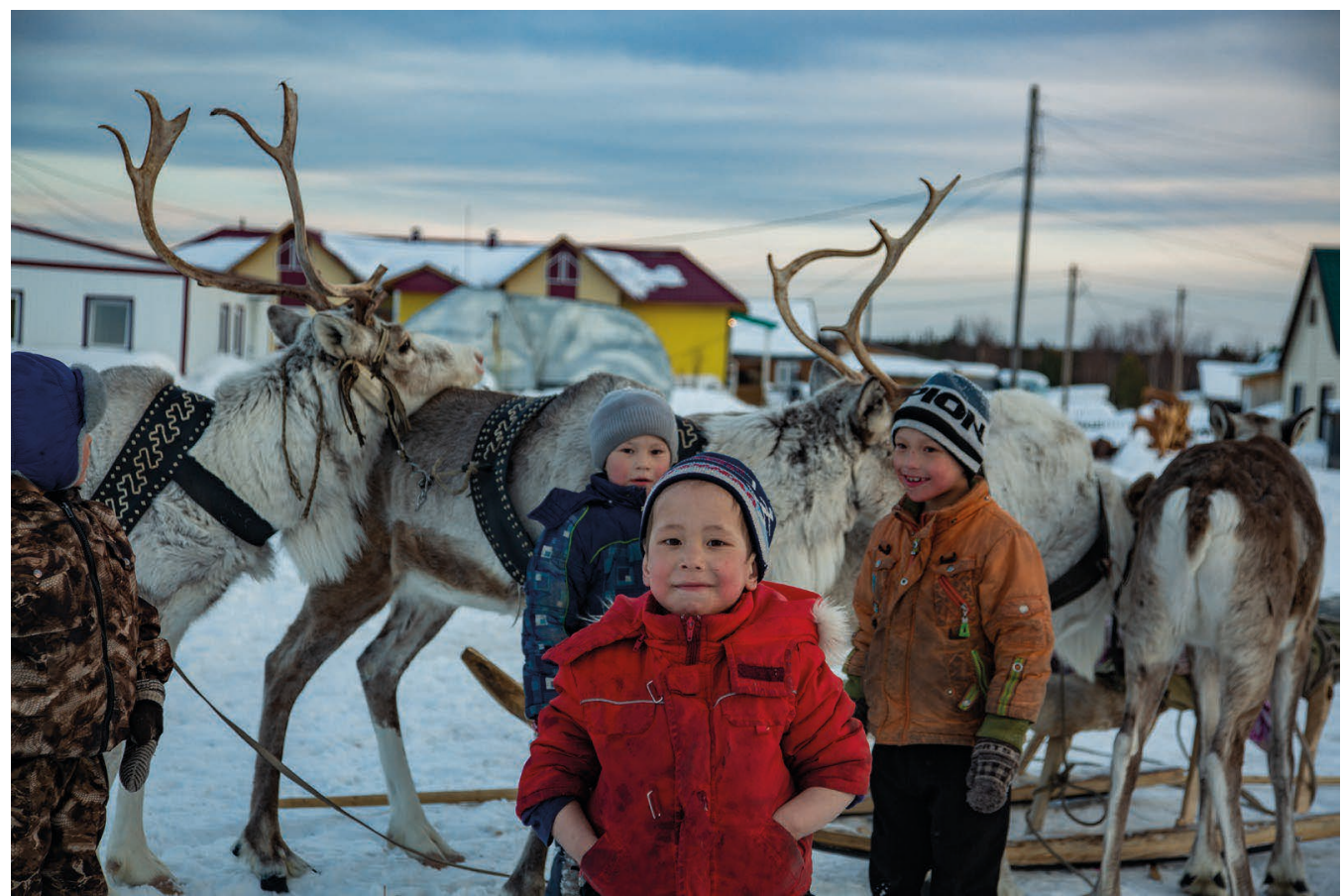

Il. 5. Chłopcy w dniu wyścigu reniferów, Ratta, Jamalsko-Nieniecki Okręg Autonomiczny, 2017, fot. A. Dybczak Muzeum Etnograficzne w Krakowie 


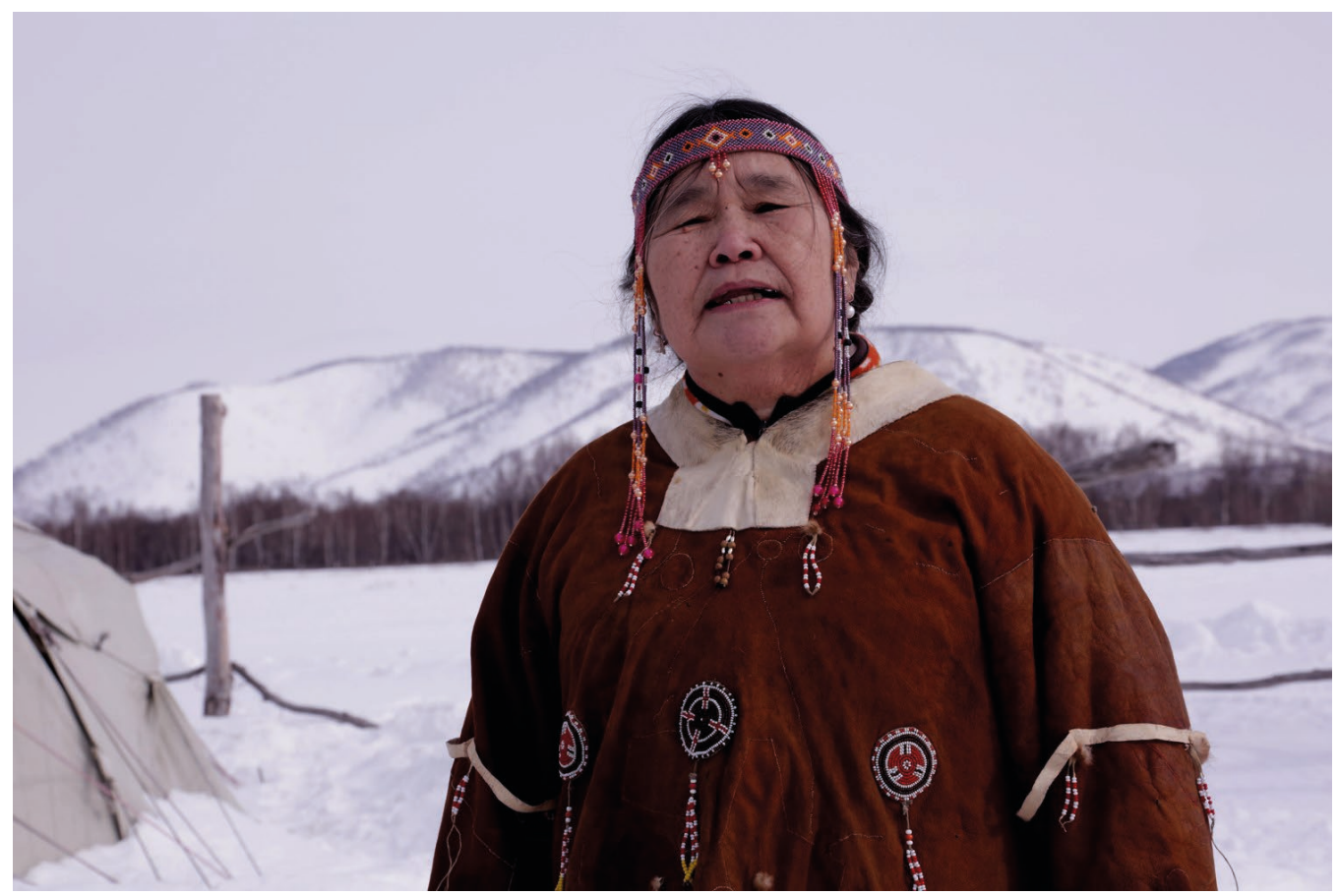

Il. 6. Lidia Innokientowna Cziczulina, Jelizewo, Kamczatka, 2017, fot. A. Dybczak, Muzeum Etnograficzne w Krakowie

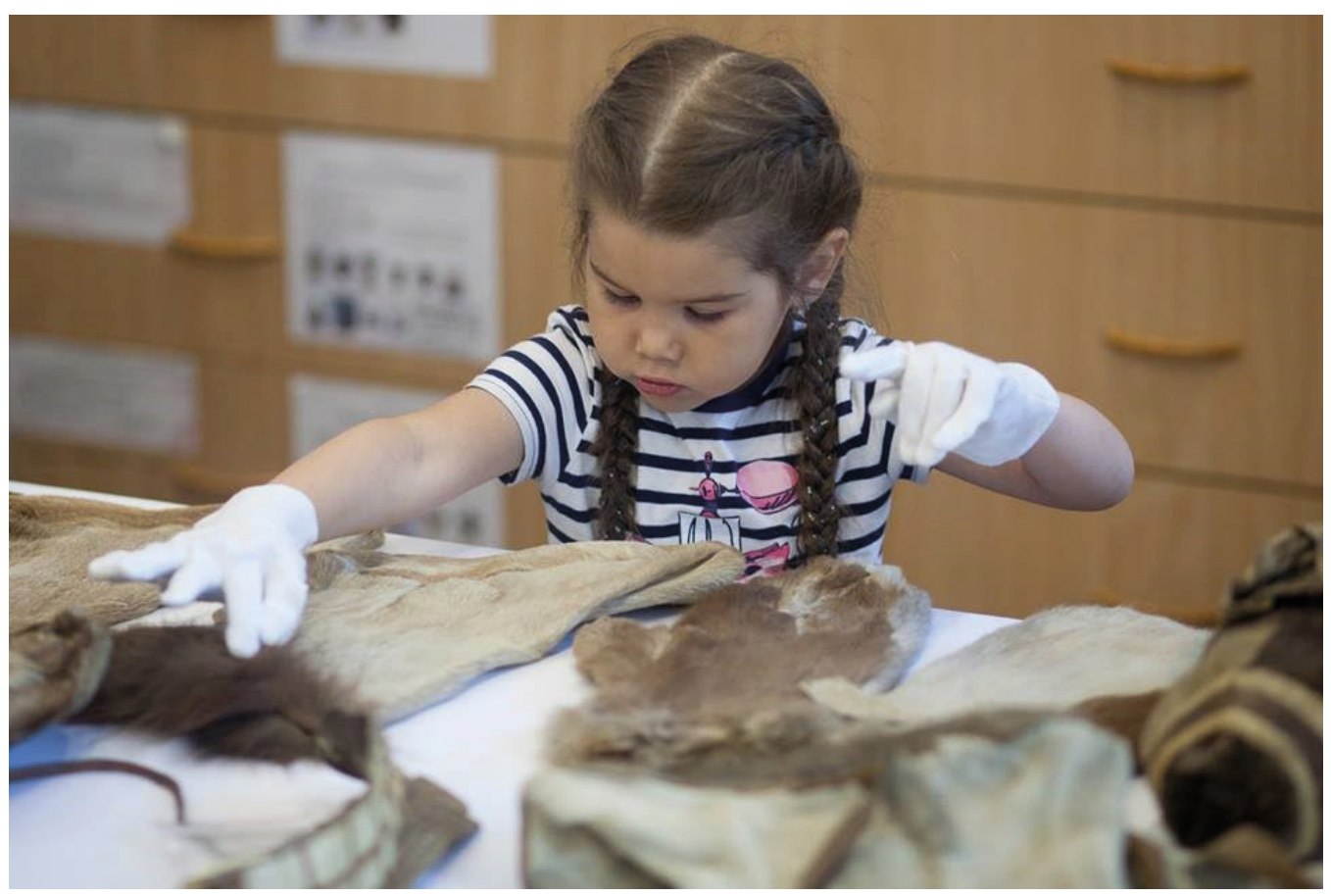

Il. 7. Wnuczka Lidii Innokientownej Cziczuliny w MEK, Kraków, 2018, fot. M. Wąsik, Muzeum Etnograficzne w Krakowie 


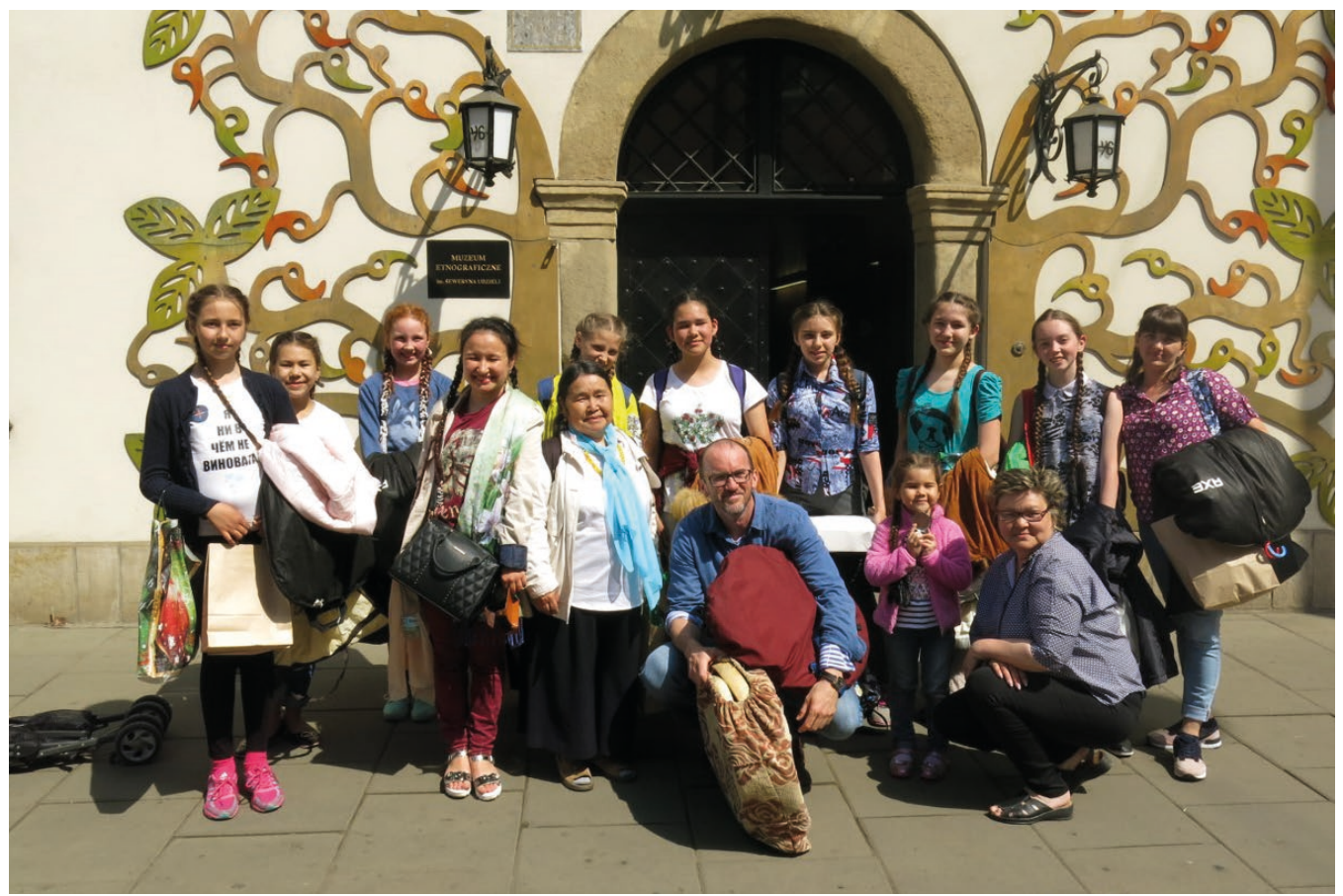

Il. 8. Zespół Lidii Innokientownej Cziczuliny w MEK, Kraków, 2018, fot. G. Kubica, Muzeum Etnograficzne w Krakowie

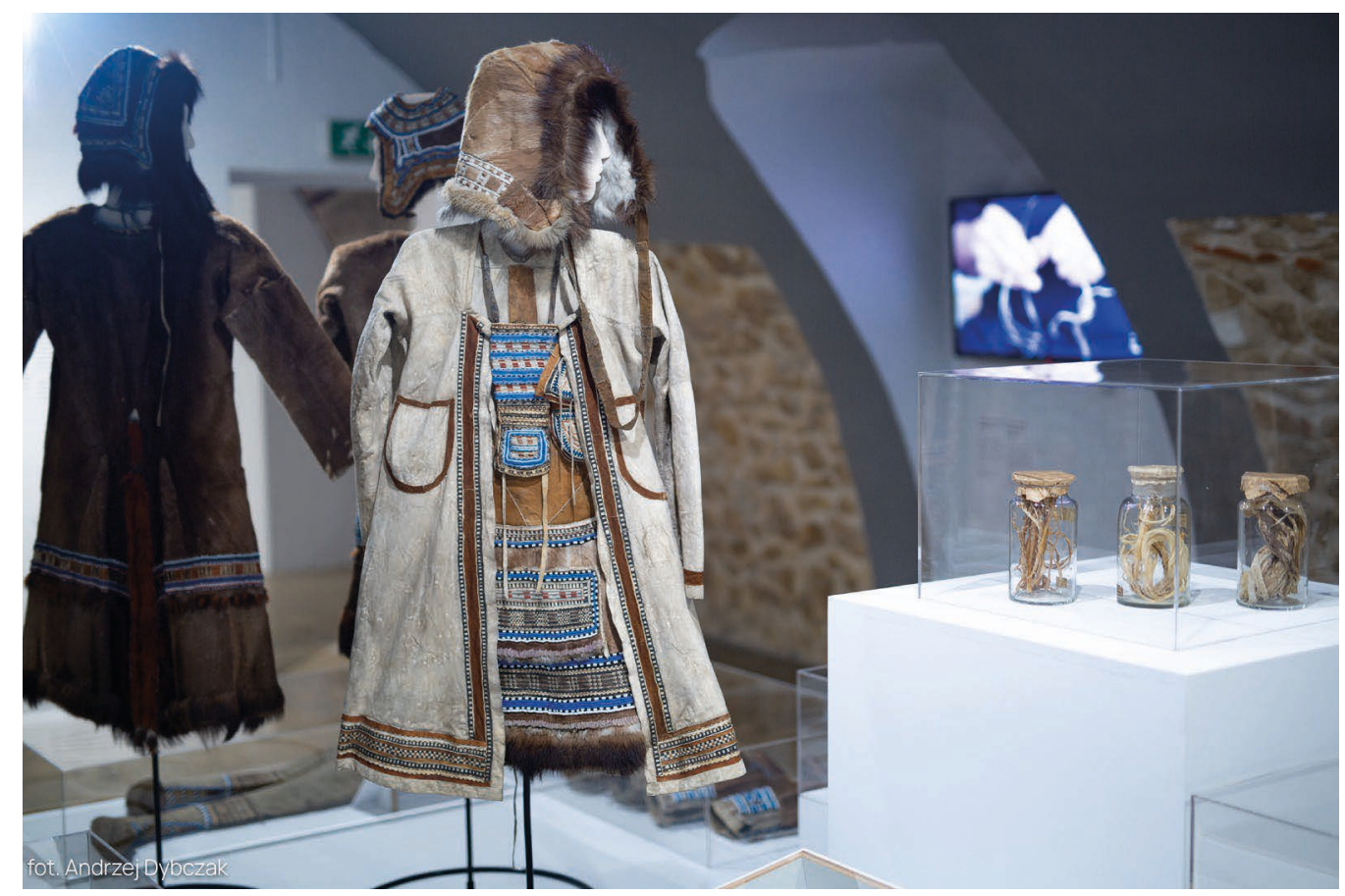

Il. 9. Fragment wystawy „Syberia. Głosy z Północy”, fot. A. Dybczak, Muzeum Etnograficzne w Krakowie 
dobnie, z tym że odbył się na przełomie marca i kwietnia 2017, i był wsparty obecnością Jurija Kwasznina, a wcześniej odwiedzinami badacza w Krakowie. Podczas tego pierwszego wyjazdu Paweł Kuboljew okazał się niezwykle ważną postacią dla interpretacji dwóch figurek z kolekcji MEK. Wiosną w Rattcie powstał materiał, który posłużył do stworzenia filmu dokumentalnego pt. Wyścig, rejestracja do filmu powstawała w ścisłej współpracy z rodziną Bojakinów, selkupskich pasterzy reniferów. Obraz będzie miał premierę na jednym $\mathrm{z}$ festiwali filmów antropologicznych.

Wczesną jesienią 2017 Andrzej Dybczak i Jacek Kukuczka pojechali do Nienieckiego Okręgu Autonomicznego (zapolarne krańce Niziny Wschodnioeuropejskiej nad Morzem Barentsa), w ślad za odzieżą nieniecką a zwłaszcza specjalnym futrzanym nakryciem głowy nazywanym kaporem, są to dary zesłańca Izydora Sobańskiego. Miejsce wybrano dzięki kontaktom Jurija Kwasznina, badaniom archiwalnym i obfitej korespondencji z różnymi osobami z tamtych stron. Pracowali tam dwa miesiące. Wspierały ich Larysa Prokofiewna, szefująca Nienieckiemu Muzeum Regionalnemu i Olga Latiszewna, autorka Tropami przodków. Zbiór materiałów ekspedycji do kanińskich Nieńców, a także wiele mieszkanek tamtych stron, dzielących się swoją wiedzą o przedmiotach z kolekcji MEK. Badania prowadzono w Narian Mar, a także w Omie, Nelmin-Nos, Krasnoje. Ich rezultatem jest opowieść Dziewczyna z północnego kraju opowiadająca o losach ludzi powiązanych z - jak się okazało - nienieckim kobiecym strojem ślubnym będącym jednocześnie strojem szamańskim. Natomiast podjęty przez mnie kontakt z Michałem Sobańskim pozwolił doświetlić biografię darczyńcy i zaskoczyć jego współczesnych krewnych syberyjską historią.

Przygotowanie do badań kolekcji etnograficznej Benedykta Dybowskiego pozwoliło zrealizować Andrzejowi Dybczakowi prace terenowe trwające dwa miesiące (marzec-kwiecień 2018), częściowo w Pietropawłowsku Kamczackim, a częściowo w osadach Milkowo, Esso, Anavgai oraz w siedliskach pasterskich w górach Kamczatki. Dużą pomoc organizacyjną wyświadczyła Natalia Tatarenkowa, etnografka pracująca niegdyś w lokalnym muzeum. Część aleucka kolekcji syberyjskiej MEK została przez nią opracowana. Pomocne okazały się także kontakty do lokalnych społeczności przekazane przez Ericha Kastena. Konsultantami kolekcji okazali się: lokalna specjalistka od ornamentów odzieży eweńskiej Maja Pietrowna Lomowcewa, pasterz Kiriak Pietrowicz, animatorka Lidia Innokientowna Cziczulina, która w maju 2018 roku zawitała do MEK wraz z grupą nastolatek z prowadzonego 
przez siebie zespołu folklorystycznego. Panie wracały z Cannes z festiwalu folkowego i zamiast zwiedzać Kraków spędziły cały dzień na studiowaniu odzieży eweńskiej z kolekcji Benedykta Dybowskiego, wystąpiły także dla pracowników muzeum na muzealnym podwórku. Dla obu stron spotkania było to wyjątkowe przeżycie. Badania na Kamczatce pozwoliły także dopowiedzieć historię eweńskiego partnera biznesowego, który sprzedał Dybowskiemu renifery umożliwiając tym samym polepszenie sytuacji gospodarczej wśród aleuckiej społeczności, Ewena Gawryłę z rodu Adukanów. Na podstronie znajdziemy opracowany album fotograficzny Dybowskiego ze zbiorów Muzeum w Pietropawłowsku Kamczackim.

Ostatnim obszarem objętym badaniami była stolica okręgu Anadyr i czukockie wybrzeże, osady Lavrentija i Uelen, gdzie Andrzej Dybczak pracował przez półtora miesiąca wczesną jesienią w 2018 roku dzięki nie bez trudu pozyskanemu pozwoleniu na pobyt przez Olgę Rostorgujewą, szefującą Centrum Dziedzictwa Czukotki w Anadyrze. Kierunek został wybrany ze względu na kolekcję Konstantego Podhorskiego, której część znajduje się w MEK (narzędzia, sztuka użytkowa, odzież) i w Państwowym Muzeum Etnograficznym w Warszawie (przeszło setka figurek i amuletów rzeźbionych w kle morsa). Uelen to najdalej na wschód wysunięta miejscowość Federacji Rosyjskiej, kilkadziesiąt kilometrów dalej jest Alaska. Życie Czukczów w tamtych stronach interesowało Podhorskiego, pisał o nich w travelogu, fotografował, a dzięki uprzejmości Adama Soboty z Muzeum Narodowego we Wrocławiu udało nam się dotrzeć do fotografii z jego albumu. Podhorski, przez chwilę gubernator Czukotki, dziecko swej epoki, stosował kolonialną perspektywę w swych zapisach ${ }^{3}$, o czym opowiadamy i na wystawie, i w materiałach prezentowanych w Internecie. Opowieść o Podhorskim nosi tytuł Złoto Alaski, złoto Czukotki, narracja przeplatana jest cytatami z jego traveloga, książki wspomnieniowej jego uniewinnionego zabójcy oraz fotografiami.

Spojrzenie uczestników badań z Uelen na samych siebie, i na moment, w którym się znajdują ujęte zostało w materiale towarzyszącym opowieści o bębnie aleuckim z kolekcji MEK — zachowana rama jest jednym z nielicznych aleuckich zabytków, pozostałe pojedyncze przykłady przedmiotów aleuckich są w Waszyngtonie i Chabarowsku. Szczególnie interesująco brzmi

\footnotetext{
${ }^{3}$ Adam Partyka przeprowadził transkrypcję skanu traveloga na tekst w ramach praktyk
} studenckich w MEK. 
opowieść Stanisława Nuteventina, artysty-rzeźbiarza w kle morsa, w filmie „Pieśń córki” opublikowanym na syberyjskiej podstronie internetowej MEK.

4.

Oczywiście nie każdy element kolekcji mógł zostać poddany tak szczegółowym analizom, natomiast nasze decyzje oparte były o staranny namysł nad tym, co w kolekcji syberyjskiej MEK stanowi największe wyzwanie ze względu na wagę dla wspólnego dziedzictwa ludzkości, w ten sposób decydowaliśmy o priorytetach naszych badań.

Zapleczem teoretycznym dla decyzji badawczych była współczesna refleksja na temat dekolonizacji zbiorów i praktyk muzealnych, czerpaliśmy także z przykładów działań autorefleksyjnych innych instytucji, bowiem wiele muzeów pracuje dziś krytycznie ze swymi kolekcjami, szukając włączających rozwiązańt. Planując badania, starałam się rozpoznać możliwości działań włączających osoby na różny sposób związane z kolekcją, tak, by rozwinąć partycypacyjny charakter tego rodzaju spotkań. Inicjowanie kontaktu na kanwie kolekcji należało do zespołu badawczego z muzeum, ale to, co wydarzało się dalej, było już wypadkową rezultatów spotkania, i dynamika wydarzeń często wykraczała poza założenia samych badań.

Jestem przekonana, że praca z rezultatami badań powinna być kontynuowana. Warto choćby sprawdzić, na ile koncepcja reinterpretacji kolekcji, opierając się na tym konkretnym zestawie praktyk, spełnia założenia pomysłu, który roboczo nazwałam w projekcie badań „muzeologią terenową”, a więc działań skupionych na poszukiwaniu żywych kontekstów kolekcji muzealnej w miejscach jej pochodzenia w sensie geograficznym, ale niezamykającym się tylko do tego wymiaru. Które działania badawcze muzealne mogłyby w takim programie zaistnieć wyraźniej? Na ile ten wariant badań proweniencyjnych ale wspartych antropologicznymi narzędziami interpretacji daje rezultaty, jakich oczekujemy od współczesnych muzeów etnograficznych? Jak te praktyki mogłyby się sprawdzić w obszarze innych kolekcji i tematów? Pytania te pozostają otwarte.

\footnotetext{
${ }^{4}$ Dobrym przykładem jest niderlandzki Research Center for Material Culture, któremu szefuje prof. Wayne Modest, czy berliński ośrodek o bardziej teoretycznym profilu, CARMAH, pod kierownictwem prof. Sharon Madonald. Przywołane miejsca refleksji działają mniej więcej od 2015-2016 roku.
} 


\section{5.}

Tworzenie powiązań między zbiorami a ludźmi lub też odkrywanie tych istniejących, wspólny czas, gdy dowiadywaliśmy się czegoś o sobie nawzajem, był jednym z ważniejszych elementów całego przedsięwzięcia. Na zakończenie naszej wielogłosowej relacji refleksja Andrzeja Dybczaka, który przeprowadził wszystkie badania terenowe tego projektu a także jest autorem materiałów wideo oraz opowieści na temat kolekcji prezentowanych na portalu „Kolekcja syberyjska — nowe spojrzenie”:

„Kiedy po raz pierwszy wchodziłem do magazynu Muzeum Etnograficznego w Krakowie, żeby zobaczyć fragmenty tak zwanej „kolekcji syberyjskiej” nie miałem pojęcia, że właśnie rozpoczyna się jedna z najciekawszych przygód mojego życia. Trwała ponad trzy lata. Teraz kiedy czasami wstąpię z ulicy do tej samej instytucji, zejdę po schodach do jej piwnicznej galerii, w której jeszcze do końca 2021 roku można zobaczyć „syberyjską” wystawę, zadaję sobie pytanie o istotę tego, czego doświadczyłem. Nie zawsze potrafimy odpowiedzieć na pytania, które sami sobie zadajemy, nie zawsze jest to łatwe zadanie. W ciemnej sali, na której powinno się kończyć zwiedzanie, a od której ja zawsze zaczynam i na której coraz częściej także kończę moje odwiedziny, są dwa przedmioty. Na ścianach fototapeta zimowego lasu tuż po zmroku, w tle niewielka drewniana chatka z komina której sączy się siwa smuga dymu. Zupełnie jakbym zstąpił do podziemi swoich własnych wspomnień, bo przecież sam to zdjęcie zrobiłem. Z czarnej gablotki odwróconej do sali plecami patrzą na mnie dobrze mi znane oczy zrobione z paciorków, znane dobrze drewniane kształty ubrane w futerka dwóch wiewiórek, jedno wiewiórki zimowej - srebrzyste, drugie wiewiórki letniej - rudawe. I wycięte z drewna usta. Ciekawe, ich twórca umiał tak je ukształtować, że bez nadawania im jakiegokolwiek konkretnego wyrazu uzyskał wiele różnych. Niczym Leonardo u Mona Lisy, ale to opowieść z innego muzeum. W tym przy ulicy Krakowskiej 48, 6 lat temu, pozwolono mi przejrzeć szufladę mieszczącą w sobie karty katalogowe eksponatów pochodzących z terenów Azji Północnej, z Syberii. Otworzyłem na chybił trafił i mój wzrok przykuły te same oczy z paciorków, ta sama zagadkowa linia ust. Wtedy patrzyły na mnie z czarno białych fotografii przyklejonych do kart katalogowych. Byłem zaintrygowany. W opisie można było prze- 
czytać, że obiekty pochodzą z ZSSR, że są to „Lalki”, i niewyraźne nazwisko: I. Żurawski, Żurowski? Byłem rozczarowany. Naprawdę to wszystko? Te dwa uczucia pozostały przy mnie po wizycie w samym magazynie. Figurki, stroje, rozmaite przedmioty z futra, skór i paciorków, lakoniczne informacje. Jaka szkoda, że przedmioty nie umieją mówić. Może opowiedziały by choć trochę ze wspaniałości świata czy światów, w których powstały? Coś o noszących je ludziach i o samych sobie? Nie wiem jak inni antropologowie kultury, ale ja wybrałem ten kierunek studiów, bo to tam można było usłyszeć najlepsze opowieści. Siedząc w magazynie muzeum pomiędzy milczącymi, pachnącymi mieszaniną skóry, wiekowego brudu i środków konserwujących przedmiotami niemal słyszałem opowieści dobiegające z tekturowych pudełek. No właśnie, niemal. Bo diabeł ukryty jest w szczegółach a od niemal do naprawdę droga daleka. Ale przecież nie tak daleka, żeby nie można jej było przemierzyć. Zebrał się zespół. Powstało założenie projektu badawczego: znajdźmy kogoś kto jest nam w stanie coś o tych przedmiotach opowiedzieć. Znajdźmy kogoś dla kogo te przedmioty jeszcze coś znaczą. Kogoś kto jest możliwie blisko ich źródła.

Każda osoba z zespołu zajmującego się tym tematem miała swój własny wkład i swoją własną drogę. Ale mnie, trzy lata projektu badawczego upłynęły na poszukiwaniu opowieści w miejscach pochodzenia przedmiotów przechowywanych w krakowskim magazynie. Niekiedy rzeczywiście udawało się je znaleźć. Można ich posłuchać czy poczytać na muzealnej wystawie i stronie internetowej www.etnomuzeum.eu/syberia. Ale najbardziej niezwykły dla mnie był moment, w którym po tych wszystkich dniach i nocach spotkań, podróży i przed komputerem, dniach i nocach pracy, zrozumiałem, że tak naprawdę nie prowadzimy badań etnograficznych ani nawet muzeologicznych. Za to budujemy niewidzialny most. Most między ulicą Krakowską 48 a lasem Keriat Kykol, a półwyspem Kanin, rozległymi wyżynami Kamczatki i czukocką plażą. Pośrodku tego mostu o pewnych porach dnia a może i nocy spotykają się przedmioty, ludzie, opowieści. Rozplątują się języki. Przypominają się zapomniane fakty z dzieciństwa. Powracają praktyki i wydarzenia. Snuje się plany na przyszłość. Chociaż most jest delikatny i może go zburzyć przejeżdżający ulicą tramwaj, to jednak warto było na niego wstąpić. I ten gest, to już jest właśnie to”. 


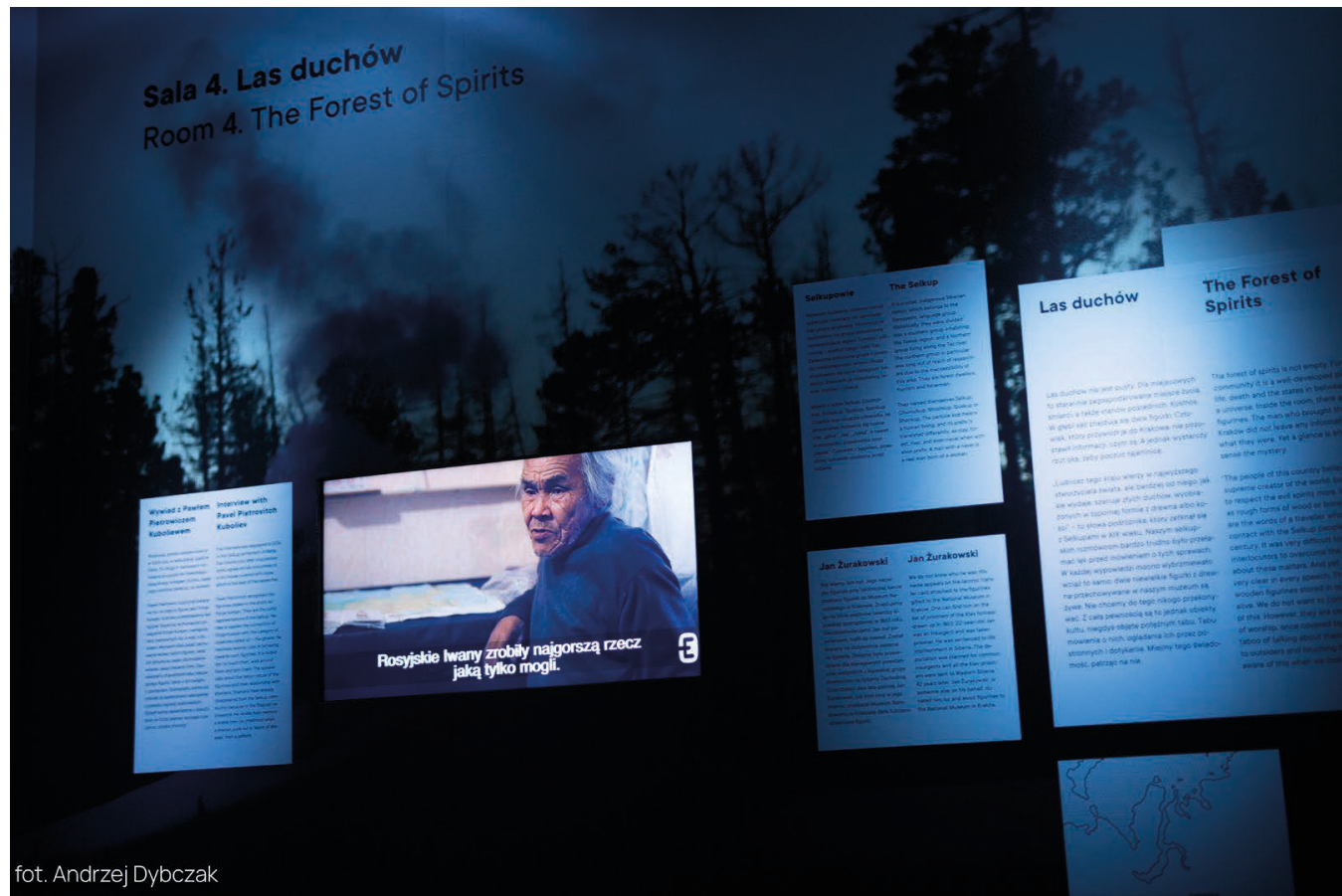

Il. 10. Fragment wystawy „Syberia. Głosy z Północy” fot. A. Dybczak, Muzeum Etnograficzne w Krakowie

\section{Kalendarium prac z kolekcją syberyjską Muzeum Etnograficznego w Krakowie wzmiankowanych w tekście:}

2008 prezentacja filmu dokumentalnego „Gugara” (reż. A. Dybczak, J. Nagłowski) w MEK, konsultacje przedmiotów eweńskich z Andrzejem Dybczakiem; który przebywał na Syberii wśród eweńskich pasterzy reniferów w 2003, 2004 i 2006 roku.

2014 kwerenda w zbiorach syberyjskich MEK Andrzeja Dybczaka, decyzja o współpracy;

2014 pomysł i przygotowanie w ramach konkursu Preludium Narodowego Centrum Nauki indywidualnego wniosku na badanie wybranych elementów kolekcji syberyjskiej, wniosek odrzucony;

Zmiana strategii: decyzja o objęciu badaniami całej kolekcji, ustalenie składu zespołu badawczego i przygotowanie do konkursu dla jednostek naukowych ogłoszonego przez Ministerstwo Nauki i Szkolnictwa Wyższego w ramach kolejnej edycji programu Narodowy Program Rozwoju Humanistyki (2016-2019), moduł „Rozwój 2a”.

2015 praca nad wnioskiem konkursowym: stworzenie założeń naukowych i hipotez badawczych w oparciu o wybrane teorie, harmonogramu produkcji, kosztorysu; tytuł projektu: „Antropologiczna reinterpretacja kolekcji syberyjskiej ze zbiorów Muzeum Etnograficznego w Krakowie, pochodzącej od polskich badaczy Syberii XIX wieku”; w grudniu moja wizyta na wystawie „Esthétiques de l’Amour. Sibérie Extrême-Orientale” w paryskim Musée du Quai Branly w ramach badań własnych; 
2016 ogłoszenie wyników konkursu, aktualizacja harmonogramu prac i roboczej bazy danych obiektów (kwiecień), podpisanie umowy nr 302/NPRH4/H2a/83/2016 w dniu 12 maja i rozpoczęcie pracy w ramach grantu: wyłonienie współpracowników do wybranych zadań (Zofia Noworól, Alicja Połukort, dr Anna Rogulska, Marcin Zybała), zorganizowanie magazynu studyjnego, dokumentacja wizualna kolekcji dla celów badań; kwerendy (m.in. Archiwum Nauki PAU i PAN, Archiwum Narodowe w Krakowie, Rosyjskie Muzeum Etnograficzne w Petersburgu, Kunstkamera - Muzeum Antropologii i Etnografii w Petersburgu, Muzeum Pitt Rivers w Oksfordzie), konsultacje (w tym materiałoznawcze), organizacja i realizacja badań terenowych na Syberii Zachodniej w Jamalsko-Nienieckim Okręgu Autonomicznym w okolicach rzeki Taz;

2017 kontynuacja kwerend (m.in. Państwowe Muzeum Etnograficzne, archiwum Zamku Królewskiego w Warszawie, Muzeum Narodowe w Krakowie, Fundacja Kultur Syberyjskich w Havel, Nienieckie Muzeum Krajoznawcze w Narian-Mar, Centrum Kultury Etnicznej Nienieckiego Okręgu Autonomicznego Narian-Mar); kontynuacja badań — wiosną ponowna wizyta nad rzeką Taz, jesienią badania w osadzie Oma w Tundrze Kanińskiej Nienieckiego Okręgu Autonomicznego;

2018 kwerendy i badania terenowe na Kamczatce (Pietropawłowsk Kamczacki, Esso, Anavgai) oraz na Czukotce (Uelen, Lavrentiya); rozpoczęcie prac nad prezentacją kolekcji i rezultatów badań na podstronie MEK we współpracy z firmą informatyczną, przygotowanie i publikacja treści tekstowych i wizualnych (w tym ponowna dokumentacja fotograficzna kolekcji - tym razem na potrzeby prezentacji);

2019 kontynuacja prac nad prezentacją wyników w Internecie, z powodu zakończenia grantu odtąd w ramach środków własnych MEK; przygotowanie scenariusza wystawy „Syberia. Głosy z Północy” i złożenie wniosku w konkursie Ministerstwa Kultury i Dziedzictwa Narodowego; pozyskanie sponsora części działań - firmy Gaz System S.A.; praca nad dwoma wnioskami grantowymi w ramach programu Horyzont 2020 z partnerami z innych krajów celem kontynuacji badań w większej sieci, udział w konkursach jednak bez wygranej;

2020 ogłoszenie wyników konkursu MKiDN; dzięki przyznanej dotacji możliwość realizacji wystawy; równolegle rozwijanie portalu z materiałami z badań oraz bazą danych o kolekcji „Kolekcja syberyjska - nowe spojrzenie” stworzonego w ramach realizacji grantu; produkcja i otwarcie wystawy w dniu 16 października (jej scenariusz zmodyfikowano i dostosowano do okoliczności; operatorem programu był NIMOZ);

2021 kontynuacja prezentacji wystawy w MEK wraz z programem rozwijającym jej wątki (online), opisanym wyżej w przypisie.

Wyniki badań były prezentowane w polskim i rosyjskim obiegu konferencyjnym; powstały także publikacje naukowe, m.in. w „Muzealnictwie” (R. 2020), w tomie podsumowującym konferencję „Darczyńcy polskich muzeów” (w druku). 
Magdalena Zych, Jacek Kukuczka, Grażyna Kubica-Heller, Andrzej Dybczak

\section{Four Perspectives. The Story about the Research Project on the Siberian Collection of the Ethnographic Museum in Kraków}

The article examines the process, methods and results of a 3-year-long research project (20162019) concerning the $19^{\text {th }}$ century Siberian collection from the resources of the Ethnographic Museum in Kraków which was donated by political prisoners, scientists and travellers. The authors discuss how the contemporary knowledge of many local experts from different ethnic groups (such as local residents, reindeer herders, whale hunters, museum staff, donators' families) combined with archival sources could help to understand the unique connections between the past and the future of such heritage and its consequences in our lives. After the research, the collection is now accessible in a digital repository along with audio and visual materials from the fieldwork and the available archive data. Some of the stories are presented also in the exhibition "Siberia. Voices from the North".

Keywords: collection, The Ethnographic Museum in Kraków, Siberia, museology, fieldwork, exhibition 